\title{
Retribution in Biblical Texts: A Stylistic Analysis
}

\author{
Riyadh Tariq Kadhim Al-Ameedi ${ }^{1} \&$ Saja Abdul Ameer Al-A'ssam ${ }^{1}$ \\ ${ }^{1}$ Dept. of English, College of Education for Human Sciences, University of Babylon, Babylon, Iraq \\ ${ }^{1}$ Dept. of English, College of Arts, University of Kufa, Najaf, Iraq \\ Correspondence: Riyadh Tariq Kadhim Al-Ameedi, Dept. of English, College of Education for Human Sciences, \\ University of Babylon, Babylon, Iraq. E-mail: alameedi.rtk@gmail.com or sajaameer9595@gmail.com
}

Received: February 1, 2018 Accepted: February 18, 2018 Online Published: March 17, 2018

doi:10.5539/ijel.v8n4p83 URL: https://doi.org/10.5539/ijel.v8n4p83

\begin{abstract}
Divine retribution is both a teaching and a core-tenet in Christianity. A large portion of Biblical texts come to embody the righteous judgment of the Almighty Lord, His gracious as well as wrath character. This paper is an attempt to pinpoint the stylistic devices and features of retribution in Biblical texts. It aims to identify the stylistic phonological, syntactic, and semantic devices of retribution in Biblical texts and find out the function of each. Furthermore, it aims to explain the overall functions such texts of retribution perform and how the overall function of these texts and the functions of the utilized stylistic devices are coalesced to produce a stylistic interpretation to these texts. It is hypothesized that Biblical texts of retribution utilize specific stylistic phonological, syntactic, and semantic devices. Besides, it is hypothesized that the functions these devices perform fall in line with the overall functions the Biblical texts of retribution have. A model is developed to analyze the Biblical texts of retribution. In addition, statistical findings are used to support the results. The findings of the analysis validate the hypotheses mentioned above.
\end{abstract}

Keywords: biblical texts, retribution, stylistic devices, conative function, referential function, stylistic analysis

\section{The Concept of Retribution: A Panoramic Vision}

The term "retribution", literary, means "repayment". It is originally derived from the old French term: "retribution" and directly from the Latin one: "retributionem" (normative retribution), where "re" means "back" and "tribure" means "to assign, to allot, to give back". Particularly," the repay that is given in return for good done or evil done (Thorndike \& Barnhart, 1968, p. 807; www.1, 2017, p. 1).

It is this idea of repayment as part and parcel of justice that confirms retribution to be of prime concern in such interrelated fields of knowledge, as philosophy, law, sociology, psychology, and theology. The meaning of retribution in these fields is centrally interpreted as giving each person his or her just moral or legal deserts. It is, inherently, right and good as well as wrong and evil.

From a theological perspective, as the only concern here, M'Caig (1915: pp. 2570-2571) enlists among other meanings to the term "retribution" the following:

1) $\quad$ AT Terms.
2) Witness of Natural Theology.
3) $\quad$ Retribution the Natural Consequence of Sin.
5)
6) Moral Sensent Implies Retribution.

In addition, he elaborates that the idea of retribution is clearly expressed in the Scripture. It comes to embody God righteous judgment, His wrath besides His gracious character. It comes to show how God's moral laws go in harmony with the physical law or laws of nature which teach that "punishment for sinners need not surprise; the fact of pardon (i.e., grace saves on certain conditions) is the surprising thing". Consequently, "the future retribution is one aspect of natural consequence of sin, yet it is also in another aspect the positive infliction of Divine wrath". So the fact of retribution is well told in "all representations of the coming day of judgment", where "the conception of God as a perfect moral governor demands that His righteousness shall be fully 
vindicated". On his part, Moule (1982, p. 241) gets retribution to mean both reward and punishment as a consequence of one's own deeds and presumes degrees of deserts and of responsibility. Both Horvath (1993, p. 17) and Bernstein (1993, p. 170) voice a similar view. To them, retribution is Divine punishment befalling the evil or blessing befalling the virtuous. It is the means by which the Almighty Lord treats people on the ground of each just deserts. Thus, Almighty Lord punishes the disobedient of His commandments and at the same time rewards the obedient. It is in accordance with everyone deeds. Wong (2001, pp. 2-3) echoes such a sense when he argues that retribution is from those "words which denote both an action and its consequence". It denotes both a positive aspect, i.e., reward and blessing for those who keep a Divine norm, as well as a negative one, i.e., deserved punishment and curse for those who deliberately violate a Divine norm. As such, retribution is a Divine appropriate and correspondent response to the righteous, who espouse the right path, plus to the wicked, who choose to oppose that path. The first party is to be blessed and rewarded and the second to be cursed and punished. This principle of perfect and just universe is based on God's righteousness. This last definition of retribution is the one adopted by the present study after being adapted from Jervis (2015, p. 324) and Kangwa (2016, p. 1).

Hence, retribution, as self-evident, falls into two types:

- Positive Retribution to the righteous in form of Divine reward and blessing for keeping the Divine norms and/or obeying the Divine commandant; and

- Negative Retribution to the wicked in form of Divine punishment and curse for violating the Divine norms and/or disobeying the Divine commandant.

Moreover, retribution runs in this life and more perfectly in the life to come. So, the other types of retribution takes into consideration the time of its implementation:

\section{- Retribution in the Present Life;and}

\section{- Retribution in the Hereafter (also known as "post-mortem retribution").}

The doctrine of retribution is developed gradually throughout the Bible. At first, the Old Testament comes to connect Divine rewards and punishments to material possessions, i.e., prosperity and poverty respectively. Obedience to the Divine norms bring with it blessing, fortune, and life, whereas curses, misfortune and death follow upon disobedience (Towner, 1996, p. 928;Fowel, 2011, p. 494). In this stage the focus is basically on traditional deed-consequence nexus, or "the destiny-producing deed" as sometimes called.

The doctrine of retribution represented by reward-and-punishment ideology, is reflected by not one of Old Testament's Books, like: Genesis, Chronicles, Covenant, Deuteronomy,...etc. It is considered, Towner (1996, p. 928) refers, as "the wisdom tradition": "Whoso diggeth a pit shall fall therein: and he that rolleth a stone, it will return upon him”.[Proverb, 26, 27].

In a while, the Old Testament exhibits reward-and-punishment ideology in an extremely different form. Here, retribution is hold as a Divine meansof humbling, testing and disciplining one's belief. Being so, it arises from what Berlejung (2015, p. 274) dubs as "crisis of wisdom". In opposition to the previous stated view of retribution, one can note, if not really touch, that there is, as Witten (1994) cited in Kangwa, 2016, p. 3) assures, no recognizable connection between wickedness and poverty, nor between righteousness and prosperity. In this regard, Towner (1996, p. 928) states: "the Book of Job is a sustained polemic against" the older view of retribution. It presents "Job" as a completely righteous person who suffers the pains of life and how his friends interpret his suffering in accordance with the older view of retribution. Inasmuch as Job's friends attempt to convince Job to confess his sin but they lose their argument against him. In a while, Job restore his previous life in all its blessing. This is a proof that Job's suffering was merely a temporary and a limited test which has no relations to His previous sins (Kaminsky, 2015, p. 301;Berlejung, 2015, p. 282).

Berlejung (2015, p. 281) asserts that "there is no real concept of individual judgment after death in the Old Testament" i.e., the Old Testament confines retribution just to the history of time. That is why the next development in retribution doctrine is to be spotted within the New Testament.

New Testament may have some references to retribution in present life where the previous view has remain prevalent up to a point. But such references are so little and not bare of relevance to retribution in the Hereafter. Accordingly, New Testament is regarded to be confined to this latter type of retribution (SeeArtherstone, 2009, p. 61). Christians believe that retribution is a sign just start in the history of time to finish in the future time (www.2., 2017, p. 3).

In fact, the real implementation of retribution is postponed, more precisely "treasured up" to the day of judgment. Noticeably, the New Testament verses, Eubank (2013, p. 243) goes on, show that human beings must keep the 
Divine norms and earn treasure in heaven to go into the kingdom and that this compensation is superbly generous. Accordingly, retribution falls into two forms:

- Eternal life and welfare, commonly described as "heaven" as a fate for the righteous; plus

- Eternal destruction and fire, commonly described as "hell" as a fate for the wicked.

Each is discussed briefly below:

\section{(A) Heaven}

The term "heaven" appears first in Old Testament as "heofon". It is originally meant "the sky" but christianized later to bear the meaning of everlasting happiness, bliss of the righteous and the dwelling of God and good spirits (Easton, 1997, p. 541; Russell, 2006, p. 275). The New Testament refers to "heaven" using numerous terms and expressions, each reflects a particular aspect of its features. Both Horvath (1993, p. 124) and Easton (1997, p. 541) enlist these terms and expressions; they include: "Father's house", "paradise", "the heavenly Jerusalem", "kingdom of heaven", "eternal life", "eternal kingdom", "eternal inheritance", "better country". Some of these terms reflect the physical features of heaven, whereas the other reflects its spiritual feature. Yet, some other may reflect both physical and spiritual features as well. In this regard, Horvath (1993, p. 124) and Russell (2006, p. 275) define heaven in terms of the kingdom of God. It refers to the Lord's sovereignty and existence. It is the place of happiness, bliss, beauty, justice, rest and joy,...etc., where the righteous people are given the dignity and grace to be with God and good spirits. Thus, heaven is where the God is "Be ye therefore perfect, even as your Father which is in heaven is perfect" [Mathew, 5, 48]. Furthermore, Horvath (1993, p. 124) as well as Russell (2006, p. 274) resort to the Book of Revelation, in particular [21: 9-27] to describe this Divine place. They depict it as a heavenly city that reveals the nature of God. It is made out of precious and very rare jewels that constitute God's throne. It is shined by the glory of God, so that it needs no further light, neither sun nor moon. Horvath (1993, p. 124) adds that it is full of trees, revisers, crowns,..etc., which symbol eternal happiness. As for the dwellers, all have no limit and will never be destroyed. They will have the name of God written on their forehead and share Jesus' throne.

From a new corner, the term "paradise" is used by Luke as well as Paul to bear the same meaning indicated by "heaven". Horvath (1993, p. 125) conveys that these terms refer to the place where the righteous accompanies Jesus under the existence of the Almighty Lord. That is why Kardec (2003, p. 24) define heaven something as the dignity and grace of being not only with, but also in Jesus and God; sharing the Divine features, viz.: beatific version, glorification, beatitude of God, and angelology

Moreover, heaven is also widely referred in New Testament by "eternal fire". Ager (2009, p. 10; 226n) argues that eternal life means to get from the Divine every good related to love and every truth related tofaith, besides, all intelligence and wisdom. In short, eternal life is a state that describes how God raises up the believers to Himself, makes them capable of "thinking about the Divine, loving it, and being thereby conjoined to the Lord" Himself.

\section{(B) Hell}

The term "hell" appears first in old English as "hel" or "helle". It originally denotes "the shadowy land of the dead", but christianized latter to bear the meaning of everlasting misery and torment for the wicked. It is the dwelling, or to be more accurate a prison, for punishment and torment of the wicked (Lewis, 1992, p. 1931; Russell, 2006, p. 275). It is a place or a state of eternal punishment for the wicked, mainly by fire (Milikowsky, 1988, pp. 239-240; Bernstein, 1993,p. 3; Collins,1996, p. 395). The New Testament refers also to hell using numerous terms and expressions. As with heaven, some of these terms reflect the physical features of hell, some others its spiritual features and still others may reflect both.

Lewis (1992, p. 1931) and Kardec (2003, p. 38) define hell as the place of Divine punishment and torment against the wicked in the Day of Judgment. Hell, in this sense, is the translated term for the Hebrew words "Gehenna and Shoal" and the Greek words "Hades and Tartarus". It is a place of "sadness and gloom", "weeping and grinding of teeth" and of God wrath against His enemies (Arav, 1992, p. 3320; Horvath, 1993, p. 132). The Book of Revelation depicts it as "a lake that burns with fire and brimstone in which the wicked will be eternally punished" (Perkins,1996, p. 413). It is "deep" and "dark" like "a prison with gates and bars and lock"; "the place of the lost" (Easton, 1997, p. 549). For instance, "and hath shut to the door, and ye begin to stand without, and to knock at the door, saying, Lord, Lord, open unto us"(Luke, 13, 25). It is without: "sun", "moon", or "stars". Besides, it is "inhospitable", "utterly" and empty of "every germ and appearance of good" (Kardec, 2003, p. 38). It is but the true meaning of what humiliation, ignominy, death, condemnation and perish is. 
Moreover, Horvath (1993, pp. 129, 133) as well as Russell $(2006$, pp. 271, 273) convey that hell is the exclusion from being with Jesus under Almighty Lord's presence. That is, to be conversely prisoned with Satan and evil spirits in such atmosphere full of envy and jealously, as torment for the wicked.

Horvath (1993, p.134) argues that the term "eternal" is used solely three time to "fire" and once to the "hell". Such a limit in using time-language led to have three interpretations, as far as the fate of the wicked is concerned. They are: Simple Death and Destruction, Eternal Damnation, or Universal Salvation. Yet, most agree with the second interpretation.

[For “Retribution in Qur'anic Text: A Stylistic Analysis" SeeAl-Ameedi\&Al-A'ssam(2018)].

\section{The Model of Analysis}

To analyze the data under scrutiny, a model of analysis is needed. Being so, the study adopts an eclectic model. It consists of three main components: stylistic devices, their functions and the overall functions of the text. The stylistic devices the study chooses to focus on are distributed over three stylistic and/or linguistic levels: phonological level to cover such devices as alliteration, assonance, consonance and rhyme; syntactic level to focus on such devices as parallelism, ellipsis, polysyndeton and hyperbaton; and semantic level to consider such devices as antithesis, simile, metaphor, and parable. These devices are identified depending on Crystal \& Davy's (1969) "linguistic level of analysis" and Leech \& Short's (2007) "figures of speech".

The stylistic functional significance of each device is considered to see how they coalesced together as well as their co-relations and co-effects with the overall functions of the text and that effect on text interpretation. In this step the study follows Lambrou's (2016) model of "Discourse stylistic".

As far as the functions of the text itself is concerned, Jacobson's (1960) communication model offers six functions. They are: conative, referential, emotive, poetic, phatic, and metalinguistic functions.

\section{Data Analysis}

\section{Text 1.}

\{13:24\} Another parable put he forth unto them, saying, The kingdom of heaven is likened unto a man which sowed good seed in his field: $\{13: 25\}$ But while men slept, his enemy came and sowed tares among the wheat, and went his way. $\{13: 26\}$ But when the blade was sprung up, and brought forth fruit, then appeared the tares also. $\{13: 27\}$ So the servants of the householder came and said unto him, Sir, didst not thou sow good seed in thy field? from whence then hath it tares? $\{13: 28\}$ He said unto them, An enemy hath done this. The servants said unto him, Wilt thou then that we go and gather them up? \{13:29\} But he said, Nay; lest while ye gather up the tares, ye root up also the wheat with them. $\{13: 30\}$ Let both grow together until the harvest: and in the time of harvest I will say to the reapers, Gather ye together first the tares, and bind them in bundles to burn them: but gather the wheat into my barn.... \{13:43\} Then shall the righteous shine forth as the sun in the kingdom of their Father. Who hath ears to hear, let him hear. \{13:44\} Again, the kingdom of heaven is like unto treasure hid in a field; the which when a man hath found, he hideth, and for joy thereof goeth and selleth all that he hath, and buyeth that field. $\{13: 45\}$ Again, the kingdom of heaven is like unto a merchant man, seeking goodly pearls: $\{13: 46\}$ Who, when he had found one pearl of great price, went and sold all that he had, and bought it. \{13:47\} Again, the kingdom of heaven is like unto a net, that was cast into the sea, and gathered of every kind: $\{13: 48\}$ Which, when it was full, they drew to shore, and sat down, and gathered the good into vessels, but cast the bad away. $\{13: 49\}$ So shall it be at the end of the world: the angels shall come forth, and sever the wicked from among the just, $\{13: 50\}$ And shall cast them into the furnace of fire: there shall be wailing and gnashing of teeth [Matthew.13, 24-50].

This text assures the certainty and inevitableness of retribution more than once in a number of parables. Stylistically, these parables represent a creative means to explain the end of the world, final judgment and retributive separation of the righteous in the kingdom of heaven and the wicked in the burning fire as Jesus' focal point or points of this text. After all, the text is of "a conative function" in that the greater preacher himself "Jesus" preaches and warns the multitudes and his disciples as well as the whole people of retribution. Many may profess to be true disciples, followers and believers but only the Day of Retribution will reveal whose faith and commitment is true and adequate. As such, the text tells that although the children of the kingdom or the righteous and the children of the evil or the wicked coexist in this life, they will be vindicated at the Hereafter. Besides, it emphasizes that the glorious kingdom of future is present in this life in an obscure and hidden way except to those with eyes of faith. So, the true believers value and appreciate the righteousness of their right path and are ready to give everything for it (www.3, 2017, p. 1).Clearly then, some verses of the text fulfill as well " $a$ referential function". 
The utilized stylistic devices and their combination confirm that more. The text is opened with the alliteration of $/ \mathrm{p} /$ to attract the receiver's attention and such a use is emphasized more by the hyperbaton "Another parable put he forth unto them". Jesus starts his first parable skillfully with a simile to attract the receiver's attention more and illuminate their insides, and that is supported more by the consonance of $/ \mathrm{n} /$ and $/ \mathrm{d} /$ respectively "The kingdom of heaven is likened unto a man which sowed good seed in his field". He wants to convey the message that the kingdom of heaven equals the Son of man is clear from any evilness and tries but to spread, sow and increase everything good including good and righteous people. Here, "good seed" and "field" are metaphorically utilized pointing out to good people_those who respect and obey the Divine norms of Jesus teaching and the present world respectively. Yet, his mission is confronted by some problems. His enemy is profited from the sleeping of some people including some of his followers, i.e., being absent from spiritual company and/or being in non-exercise of grace to spread, sow, increase everything bad and evil including evil people "But while men slept, his enemy came and sowed tares among the wheat". Such people are compared implicitly to "tares", i.e., darnel which is a poisonous weed organically related to "wheat" and difficult to distinguish from it in its early stage of growth (www.4, 2017, p. 3). So they are completely harmful. In contrast, the good people or the righteous are compared implicitly to "wheat" being completely useful.

Besides, the metaphor of "sleeping" as well as that of "tares" and "wheat", there is a kind of parallelism as well as a multiple-antithesis between the first verse of the text and the second (See the text above). While the first of these stylistic devices increases the persuasion of the text, the second contrasts the good done of the Son of man as part of His Divine duty to the evil done of the devil who trespasses to prevent and destroy. Thus, for Jesus being engaged with teaching the Divine norms that gives an opportunity to his "enemy", i.e., the devil to spread as well his evilness. As such, it is something out of humans control that the good and the evil coexist in this world and they may grow next to each other in such a way that one may not be able to recognize between them. But such a state will not continue forever because at the end of the world the people of true faith will be realized and rewarded as those who follow their devils and be punished. Consequently, the evil with their evilness will be ended in a burning fire. That will make the kingdom of heaven once again full but with goodness and the good.

However, grasping the interest and attention more, the alliteration of different sounds, besides the assonance of $/ \mathrm{N} /$ and $/ \mathrm{J}: /$ and the consonance of $/ \mathrm{t} /$ are all employed, giving a nice and a slow rhythm, particularly for being accompanied by hyperbaton" But when the blade was sprung up, and brought forth fruit, then appeared the tares also". So, when the two kinds of seeds come out "the servants" _ as a metaphor describing the true followers of Jesus or the "the householder" as another metaphor_came and asked him in such a manner that reveals and expresses not only their reverence and obedience calling him "Sir", but also their surprise, disappointment and anxiety at the discovery of the evil or the wicked among them. Being told that "an enemy" repeated for emphasis_has done this, motivates them to post a further question in which they wonder if they have the right to go and gather them up; seeking a solution for such a problem. As a pervasive feature along the text, the engagement of the receiver's attention and interest is fulfilled in these lines via the alliteration of $/ \mathrm{s} /, / \mathrm{\delta} / \mathrm{dnd} / \mathrm{g} / \mathrm{and}$ the consonance of $/ \mathrm{d} /$ as well as by positing the question itself "Wilt thou then that we go and gather them up?". That question gets not only a negative answer but also an explanation which stylistically rich with parallelism, a repetition of the metaphorical terms "tares and wheat" which give it its desired persuasive effect "Nay; lest while ye gather up the tares, ye root up also the wheat with them".

However, the willingness of the "servant"to uproot the "tares" was prevented in order not to endanger the wheat. Both roots were already intertwined. Yet, not far that it would easy to distinguish between the two. Jesus tells that Almighty Lord tolerated the wicked in the present life for the sake of his elect. That is, Almighty Lord avoids uprooting the young darnel because He values the wheat. However, such a state will not last for long as the time will come when Almighty Lord publicly distinguishes between them. The appointed time is Day of Retribution, implicitly compared to the "harvest"for their resemblance. It partakes in enhancing and intensifying the meaning more and brings the picture near to the receiver's mind "Let both grow together until the harvest". At the "harvest", this responsibility will be given to specific angles of Almighty Lord "the reapers" as metaphorically pointed for the same purpose above indicated. Thus, it is not the responsibility of anyone else who may randomly put himself into that position. Worth to mention, while the text refers to Jesus metaphorically twice earlier as "man", and "householder" respectively, in these lines of the text a direct reference to Jesus is made. This time the first personal pronoun "I" is used to emphasize that it is the Jesus who gives the final judgment on the Almighty Lord behalf. Such emphasis is confirmed more with the repetition of "harvest". So, in the Hereafter those with true faith and goodness will be realized easily from those with false faith and evilness "and in the time of harvest I will say to the reapers". As a first step of punishment, there will be a separation between the righteous and the wicked. Here, a multiple antithesis accompanied with structural parallelism is used to confirm the big contrast between the 
retribution of the two parties. Again "tares" and "wheat"are indicated to stress the meaning more. The "reapers" will "gather together" and "bind in bundles" the wicked "tares" as an indication to their complete separation from the righteous over and above to their future condition where they will be chained and tied tightly with other wicked who might be of the same degree of evilness. Then, they will be casted into a burning fire where they face but the wrath of Almighty Lord which will be everlasting and unquenchable. By contrast, the reapers will gather the righteous and let them enter the kingdom of heaven and be blessed by being with Jesus in "My barn". Here, the first personal possessive pronoun "My" with the metaphorical term "barn"are employed to confirm the meaning My kingdom, as where I am. In fact, it adds much more majesty and luxuriousness to the reward that wait the righteous as a retribution to their good done "Gather ye together first the tares, and bind them in bundles to burn them: but gather the wheat into my barn". That is why the righteous there will "shine forth as the sun" in perfect holiness nature and in all prosperity of soul; resemble the sun in having no spot in them or upon them. They bright as the sun "Jesus Himself" the use of a simile, here, is but an emphasis to the above meaning of majesty and luxuriousness that the righteous will be all under the glory of Almighty Lord in His Kingdom. Jesus, here, is preaching and/or teaching for more emphasis demanding all the people to listen carefully to His teaching and act accordingly. That enforced more by the rhythm of this line resulting from the alliteration of $/ \mathrm{h} /$ and the assonance of /ro/.

Regarding the second parable, again it begins with a simile where the concern once more is with the kingdom of heaven. It is equated this time to "a treasure hid in a field". It is similar to a treasure in that it is really as valuable and precious as treasure deserves to give and relinquish everything no matter what pleasantly to win it. Meanwhile, it is not similar to any treasure but "a hidden" one as it can only be found, reached and appeared to those with true faith, strong desire and readinessto give everything and pay every cost. In addition,the consonance of $/ \mathrm{d} /$ and $/ \Theta /$ participate with the polysyndeton in giving this parable its memorable impact, rhythm, and supports the continuity and flow of the expressed image "the which when a man hath found, he hideth, and for joy thereof goeth and selleth all that he hath, and buyeth that field".

Making that meaning unforgettable, a third parable is supported with a parallel syntactic structure and to far a point sameness in meaning to the forgoing one. This time "the kingdom of heaven" bears the image of "a merchant manseeking goodly pearls". Again finding such a precious pearl demands true faith, patience, strong desire and constant hard work. Thus, the kingdom of heaven metaphorically resembles a pearl of great price. But a true believer or follower, as explicitly compared to truemerchant, can recognize it well, giving its real value. Being wise enough to invest his life in, such a merchant does not care a bit for whatever it costs. Also this parable is with slow rhythm. The rhythm is created by the use of not only polysyndeton but also the alliteration of $/ \mathrm{h} /$ and the consonance of $/ \mathrm{n} /$ and $/ \mathrm{d} /$ respectively which accompany the simile, parallelism and the above various metaphorical illustrated terms.

However, the last parable, included within this text of retribution, comes to reemphasize the focal points already presented in the first parable, i.e., recurs the same theme. Such a similarity in meaning is underpinned more by having a syntactic parallelism with it. It underlines, first, the mingling of the righteous with the wicked in this life. Second, it accentuates the coming separation between the two parties and what each will receive according to the Divine law of retribution.

A long with the above parables the start once more is with a simile. "The kingdom of heaven" this time is compared to "a net cast into the sea" where "sea" is a metaphor point to the present world. Such a stylistic use of a simile and a metaphor together with the consonance of $/ \mathrm{t} /$ and $/ \mathrm{d} / \mathrm{helps}$ in engaging the receiver attention and evoking their thinking. That is especially correct if to know that some of the Jesus followers and disciples worked at fishing, besides, they were near the lake known as "Galilee" (www. 5, 2017, p. 1). Normally, the net does not discriminate in its catch; gathering "every kind": generalization. So, in the present life no separation and may even in some cases no identification is there between the righteous and the wicked. They predestinated to co-exist with each other on this earth until the end of the world. Only then, the process of separating the righteous from the wicked begins. However, the personal pronoun "they" is used, in verse $\{13: 48\}$, cataphorically with "angles", in the verse that follows, as a repetition conveying an emphasis to suggest exactly the meaning already carried and illustrated by "reapers". Another repetition carrying the same function, i.e., emphasis, is that of the antithesis "good/bad" with their synonyms "just/wicked", "and sever the wicked from among the just". The emphasis is strengthened more by the hyperbaton "So shall it be at the end of the world". It is worth to note that the alliteration of $/ \mathrm{w} /$ and the consonance of $/ \mathrm{t} /$ over and above the repeated alliteration of $/ \mathrm{t} / \mathrm{and} / \mathrm{d} / \mathrm{in}$ this parable supports further the low rhythm of the whole text.

So, while all "the good" will be treated kindly, rewarded and lead honorably to heaven as metaphorically signified by "gather into vessels", all the "the bad" will be treated severely, punished and casted into the lake that burns 
with fire and brimstone as metaphorically suggested by "furnace of fire". Necessary to note that, the use of "and", i.e., polysyndeton with subject ellipsis and hyperbaton is intended to evoke the receivers emotion and imagination while describing continually how severely they will be treated "And shall cast them into.". Furthermore, the multiple antithesis, here, is used to show again how big the contrast between the retribution of the righteous and that of the wicked is. To reinforce the last image more "wailing and gnashing of teeth" are used to describe more the sever retribution that waits the wicked. After all, the text reveals that retribution in its certainty and inevitableness is a choice given by Almighty Lord to His people.

All in all, the four parables partake together with the stylistic devices they contain in captivating the receivers, evoking their thought, making the meaning more memorable and creating a strong persuasive impact.

\section{Text 2.}

$\{25: 31\}$ When the Son of man shall come in his glory, and all the holy angels with him, then shall he sit upon the throne of his glory: $\{25: 32\}$ And before him shall be gathered all nations: and he shall separate them one from another, as a shepherd divideth [his] sheep from the goats: $\{25: 33\}$ And he shall set the sheep on his right hand, but the goats on the left. \{25:34\} Then shall the King say unto them on his right hand, Come, ye blessed of my Father, inherit the kingdom prepared for you from the foundation of the world: $\{25: 35\}$ For I was an hungred, and ye gave me meat: I was thirsty, and ye gave me drink: I was a stranger, and ye took me in: $\{25: 36\}$ Naked, and ye clothed me: I was sick, and ye visited me: I was in prison, and ye came unto me. $\{25: 37\}$ Then shall the righteous answer him, saying, Lord, when saw we thee anhungred, and fed [thee?] or thirsty, and gave [thee] drink? \{25:38\} When saw we thee a stranger, and took [thee] in?or naked, and clothed [thee?]\{25:39\} Or when saw we thee sick, or in prison, and came unto thee? \{25:40\} And the King shall answer and say unto them, Verily I say unto you, Inasmuch as ye have done [it] unto one of the least of these my brethren, ye have done [it] unto me. \{25:41\} Then shall he say also unto them on the left hand, Depart from me, ye cursed, into everlasting fire, prepared for the devil and his angels: $\{25: 42\}$ For I was an hungred, and ye gave me no meat: I was thirsty, and ye gave me no drink: $\{25: 43\}$ I was a stranger, and ye took me not in: naked, and ye clothed me not: sick, and in prison, and ye visited me not. $\{25: 44\}$ Then shall they also answer him, saying, Lord, when saw we thee anhungred, or athirst, or a stranger, or naked, or sick, or in prison, and did not minister unto thee? \{25:45\} Then shall he answer them, saying, Verily I say unto you, Inasmuch as ye did [it] not to one of the least of these, ye did [it] not to me. \{25:46\} And these shall go away into everlasting punishment: but the righteous into life eternal. [Matthew, 25:31-46].

This text depicts a tremendous picture of universal retribution in a form of a parable. As a favorite stylistic choice in Jesus' teaching, this parable sets forth some Divine realities related to retribution. It conveys that at the end of the world:

- "The son of the man" is the judge on Almighty Lord behalf;

- All humans must give an account of what they have done during their life;

- There is a separation between the hypocrites/false believers from the real/true believers;

- There are some surprises; and

- Deeds are the evidence of salvation.

- As such every man shall be sentenced to everlasting happiness or misery.

Telling all these facts of retribution by the great preacher Himself, i.e., "Jesus" to his disciples, on the Mountain of Olive, the text obviously performs "a referential function".

However, the text has a further prime function. It serves, with no doubt, "a conative function" where it is seen as a sermon of caution (www. 6, 2017, p. 3). Its application is: "watch therefore and be you also ready".

The vocabularies and the various stylistic devices it contains over and above the deliberate and clear repetition of some of them all partake not only in making the receivers remember well all these facts, but also in forming and conveying, as Bruner (1990, cited in www.7, 2017, pp. 10-11) comments, the meaning of both "a promise" and "a warn". A promise of bless to those people who show mercy and "an invitation" to them to watch for opportunities to minister. Meanwhile, it is a warning of cruse to the opposite people and, hence, "an intimidation" against pretending faith while living a selfish life. Consequently, it tries to waken the receivers with at most care and diligence to be ready for the final judgment and retribution.

The text is opened with such assertion that "the Son of the man" will be back at the end of the age with absolute Divine support. He will be supported Divinely with "his glory", as a symbol to the great power and authority, including the judicial authority, he will be with. Also, He will be accompanied by a glorious retinue, his holy myriads and/or ministering sprits; be implicitly compared to "holy angles" "and all the holy angels with him". 
They will be with Him both for state and service. They come to call the court, to gather the elect (See Matthew. 24: 31), to bundle the "tares" (SeeMatthew. 13:40), to be witnesses of the righteous happiness and the wicked misery, and to do all that needed from them at this great solemnity.

In fact, such a return is but the beginning of retribution and final judgment. Clearly, the text insinuates how such a Divine duty is bestowed honorably to a human. The Almighty Lord gives "the Son of the man" the dignity to be the "Judge", the "King" or the "Lord", as the text itself emphasizes and denotes later; for by him Almighty Lord will judge the world. This idea is expressed metaphorically in "then shall he sit upon the throne of His glory", i.e., the throne of justice. To increase the receiver attention more this fact is expressed with a hyperbaton. Worthy to note that the repetition of the term "his glory" with "throne" conveys the meaning that "his throne", i.e., the absolute power and authority of "the Son of the man", is below the throne of the Almighty Lord and as such under His will. Boston (1850, p. 289) affirms this meaning saying in his comment on this text: "the judging of the world being an act of the royal mediators' kingly office".

Obviously then, the text is concerned with showing the "how" meanwhile hiding the "when" of this back and return. The text employs future time "shall come", "shall he sit" to imply the meaning in "a day" and in "an hour" of which humans are not aware (See Matthew. 24:50). The time, as such, is left open to warn humans about living responsibly and be ready for the coming of "the Son of the man".

However, being placed as a judge, every human no matter who, where, and/or when is, was, or will be on the face of the earth, all shall be summoned in front of His tribunal. While the total inclusion is indicated by the term "all nations" in its generic meaning, the use of hyperbaton with a polysyndeton secures an emphasis to this meaning and the passive implies that it is the Almighty Lord, Who, may be through the instrumentality of the "holy angles" gathers, "all nations" "And before him shall be gathered all nation". Then, the separation is to start. Incidentally, the parable uses "simile" to convey the message that "the Son of the man" equals a "shepherd". Both are similar in treating those under their care gently, tediously and with tremendous love, and mercy, as well as providing their needs. Not only this, a metaphor is used twice embarking antithesis to make the parable more clear and lively while connecting its ideas vividly and systematically; on the one hand, to reflect the underlying resemblance between "sheep" and "the true believers"; and between the "goat" and "the false believers/ hypocrites", on the other "as a shepherd divideth [his] sheep from the goats". The sheep and the true believers are alike in trusting and depending entirely on their Almighty Lord Who cares for all their needs. Thus, they are calm in His presence and more obedient. Instead, the goats and the false believers share more than one negative feature, such as being: selfish, independent, concerned only with themselves; besides, they love doing what they want more than they love pleasing their Lord. Noticeably, Jesus in this text is concerned with showing the retribution, and consequently the separation, of sheep and goats; not that of sheep and wolves. This choice comes to show that the divergence between these very similar types is not hidden to their shepherd and appears very clearly to all others at the end of the day. Simply to put, Jesus tries, as Cue $(2017$, p. 1) points out, to convey that many may pretend believing and loving Almighty Lord, observing the right rituals and saying the right things but in reality refuse living a changed life that loves other as He loves them. So, deciding to separate who is a "sheep" and who is a "goat" is the first thing "the Son of the man" and/or the "shepherd" is going to do in His return.

As a first consequence to this separation, the true believers will be set in a favored position as metaphorically denoted by "on his right hand". The false believers, in contrast, will be set in disfavored position as metaphorically and briefly expressed by "on the left". For the purpose of emphasizing the contrasted fates of both, antithesis with "but" as a conjunction are utilized in this verse, "And he shall set the sheep on his right hand, but the goats on the left". However, the real consequence of such separation is but to begin. "The Son of the man" in the following verses is implicitly compared to "the king" to bring His leading role in that day more to the focus. Therefore, the king will give his order in a term of warm invitation to the merciful humans who are already separated in a position of favour to proceed further and enjoy the Divine "gift" the Almighty Lord prepares for His people. The ellipsis with "come" and the absence of a conjunction with the second order "inherent" are intended to show the close connection between the first and the second while throwing more light on the second "Then shall the King say unto them on his right hand, Come, ye blessed of my Father". Necessary to note, the term "inherent" clearly suggests that the reward this group deserves to receive as a consequence of their good deeds is but nothing if contrasted to the Divine bliss, happiness and luxury they are going to be. It is only the Almighty Lord Who makes them heirs of heaven which is prepared for them at the beginning of creation. i.e., salvation, from the beginning, is Almighty Lord's purpose. Here, the alliteration of /f/ helps to generate and reinforce the musical quality of the text.

So what does this group of people do to be granted with heaven? The king names six deeds of mercy done to 
Him as an answer to such a proposed question. They are: food, drink, hospitality, nursing, care and visitation. Of course this list is but illustrative and not exhaustive. Each meets a particular need of a particular needy person; all of them are within the reach of every human. The short parallel sentences in term of cause and effect, the pervasive assonance of/i/ in all of them and the repetition of "I and $m e$ " participate, where each stylistic device supports the other, in transmitting and reinforcing the aforementioned message in a vivid and fresh way and creating a memorable rhythm; thus be more persuasive and effective. Such effect continues to present along the successive verses which utilize and repeat, to far a point, not only the same stylistic devices (parallelism, polysyndeton with "or" instead of asyndeton, assonance of /I/ and the repetition of "we and thee") but also vocabularies; to be presented this time in a form of questions to express the wonder and the elements of surprise the righteous will be with. They cannot imagine when they have done and extended such deeds of mercy to the king, especially if they have not live during His time. Moreover, the verses \{25:37-39\} come in forms of questions and preceded by "then"to express their relevance to the previous verses and the unity of their message. Such a use is immediately followed by a hyperbaton to emphasize, with the polysyndeton between them, their stunned surprise. Be mercy-givers make them creditable to be described as the "righteous". These verses also contain the term "Lord" to refer back to the "king" which in itself refers back to "he" and are all anaphora to "the Son of man". "The king" will explain to these astonished mercy-givers, while emphasizing the truth of what he says in "verity I say unto you", that showing mercy to any person in need means showing mercy to him. "The king" in this exact verse identifies Himself with those in need and put them as His brothers to reinforce the importance of loving and showing mercy to others in need and attempting to alleviate their pain.

The seriousness of helping the needy can be seen in the severity of the king's words that are directed to the false believers; especially with the aid of parallelism and antithesis (See the text above). That is they come in a parallel form and reverse in meaning to his words with the righteous. Here, the king will direct his talk to the damned humans dismissing them away from him. He judges them into eternal fire as a deserve consequence of their wrong choice. They choose to spend their eternity with devil and his angles with whom they have allied in their earlier life. Fire is not created for them, if contrasted to heaven, but their sins and rebellions send them there.

Stress the message more, the verses $\{25: 42-44\}$ come with exact repetition to the vocabularies and the utilized stylistic devices that are already utilized in pinpointing the six deeds of mercy, the wonder and the stunned surprise of the righteous. However, the only one difference is the addition of "no" and "not" as negative devices to reverse the meaning. Therefore, they echo the same persuasion and effectiveness. That is what makes these verses reflect explicitly that the sins of this group of people is that of omission rather than sins of commission. They fail to do the deeds of mercy that they could have done. Simply to put, their failure to do good things is as cursed as doing bad things. The king explains with emphasis to the mercy-preventer that showing no love and mercy to any person in need_as indicated in "the least of these" where "these" has an anaphoric reference to "brother" _ means prevent their love and mercy to him. Then, he shows and emphasizes the big contrast, in form of antithesis, the fate of mercy-givers and mercy preventers. The first group is to be in eternal bliss and happiness as implicitly compared to "life". By contrast, the second group is to be in everlasting fire, misery and punishment. However, the polysyndeton confirms more the relevance of this last antithesis to all of the previous antithetic parallelism, "And these shall go away into everlasting punishment: but the righteous into life eternal".

In short, the text in its high and rich style attempts through utilizing different stylistic devices, that are already highlighted, to depict the universal retribution in the Hereafter in such a way that any text receivers will but imagine themselves in front of the "son of the man" tribunal. Crucial to call attention to this point that the study throughout the aforementioned interpretation of the text concentrates on the scene of retribution and avoids coming across to answer "who is the son of the man?". Most Christian commentators are of the opinion that the "son of the man" is Jesus Himself. However, the study looks at this opinion with some preservations. In addition, the clear repetition of vocabularies and stylistic devices within the text as well as its short phrases play a part in creating a hurried rhythm. The latter reflects more the importance of what Jesus try to teach. Relevant to this point, the text is full with /m, n, $1 /$ spread over it a softness sense (Clymer, 2008, p. 7). The text emphasizes continually along its verses that retribution, in terms of exclusion or inclusion into the kingdom of heaven, is a choice in humans' hands. Such a choice entails no great sacrifice at all.

\section{Statistical Analysis}

The statistical analysis is limited to the stylistic devices and the overall functions of the retribution texts in the Holy Bible.

(i) The stylistic devices

The stylistic devices have been used for (139) in Biblical texts of retribution. (15.11\%) of stylistic devices in 
retribution texts are of alliteration, consonance and metaphor respectively. Stylistic devices of assonance form $(11.51 \%)$. Those of parallelism are $(10.79 \%)$ and those of polysyndeton are (8.63). The stylistic devices of hyperbaton form (7.91\%) and those of Ellipsis as well as of antithesis form (7.19\%), i.e., both these devices score similar in retribution texts. (4.32\%) of stylistic devices in the retribution texts are of simile and the stylistic devices of parable form (3.60\%). Table (1) shows the stylistic devices in Biblical texts of retribution.

Table 1. The stylistic devices in biblical texts of retribution

\begin{tabular}{|c|c|c|}
\hline STYLISTIC DEVICE & Uses & Frequency \\
\hline Alliteration & 21 & $15.11 \%$ \\
\hline Assonance & 16 & $11.51 \%$ \\
\hline Consonance & 21 & $15.11 \%$ \\
\hline Parallelism & 15 & $10.79 \%$ \\
\hline Ellipsis & 10 & $7.19 \%$ \\
\hline Polysyndeton & 12 & $8.63 \%$ \\
\hline Hyperbaton & 11 & $7.91 \%$ \\
\hline Antithesis & 10 & $7.19 \%$ \\
\hline Simile & 6 & $4.32 \%$ \\
\hline Metaphor & 21 & $15.11 \%$ \\
\hline parable & 5 & $3.60 \%$ \\
\hline Total & 139 & $100 \%$ \\
\hline STYLISTIC DEVICE & Uses & Frequency \\
\hline Alliteration & 21 & $15.11 \%$ \\
\hline Assonance & 16 & $11.51 \%$ \\
\hline Consonance & 21 & $15.11 \%$ \\
\hline Parallelism & 15 & $10.79 \%$ \\
\hline Ellipsis & 10 & $7.19 \%$ \\
\hline Polysyndeton & 12 & $8.63 \%$ \\
\hline Hyperbaton & 11 & $7.91 \%$ \\
\hline Antithesis & 10 & $7.19 \%$ \\
\hline Simile & 6 & $4.32 \%$ \\
\hline Metaphor & 21 & $15.11 \%$ \\
\hline parable & 5 & $3.60 \%$ \\
\hline Total & 139 & $100 \%$ \\
\hline STYLISTIC DEVICE & Uses & Frequency \\
\hline Alliteration & 21 & $15.11 \%$ \\
\hline Assonance & 16 & $11.51 \%$ \\
\hline Consonance & 21 & $15.11 \%$ \\
\hline Parallelism & 15 & $10.79 \%$ \\
\hline Ellipsis & 10 & $7.19 \%$ \\
\hline Polysyndeton & 12 & $8.63 \%$ \\
\hline Hyperbaton & 11 & $7.91 \%$ \\
\hline Antithesis & 10 & $7.19 \%$ \\
\hline Simile & 6 & $4.32 \%$ \\
\hline Metaphor & 21 & $15.11 \%$ \\
\hline parable & 5 & $3.60 \%$ \\
\hline Total & 139 & $100 \%$ \\
\hline
\end{tabular}

Biblical texts of retribution perform the conative function as well as referential function. That is why these two functions scores $(50.00 \%)$ in retribution texts. However, the other communicative functions seems to have no significant role in these texts. Table (2) shows the overall functions retribution texts in the Holy bible perform. 
Table 2.The overall functions of retribution texts in the holy bible

\begin{tabular}{lll}
\hline The Functions of the Text & Uses & Frequency \\
\hline Conative Function & 2 & $50.00 \%$ \\
ReferentialFunction & 2 & $50.00 \%$ \\
Emotive Function & 0 & $0.00 \%$ \\
Poetic Function & 0 & $0.00 \%$ \\
Phatic Function & 0 & $0.00 \%$ \\
Metalingual Function & 0 & $0.00 \%$ \\
Total & 4 & $100 \%$ \\
\hline
\end{tabular}

\section{Conclusions}

This paper arrives at the following conclusions:

1). The findings of the stylistic and statistical analyses verify the hypotheses set by this paper. Precisely, retribution in Biblical texts utilizes certain stylistic phonological, syntactic and semantic devices and features to achieve theirfunctions. These include such devices as alliteration, assonance, consonance, parallelism, ellipsis, polysyndeton, hyperbaton, antithesis, simile, metaphor and parable.

2). Retribution texts are rich with not only one form of stylistic devices but rather different forms of them. The statistical analysis have shown that the highest percentage $(15.11 \%)$ is divided equally among alliteration and consonance as stylistic phonological devices and metaphor as a stylistic semantic device, whereas the next heights percentage is that of assonance to be followed by parallelism, polysyndeton, hyperbaton, ellipsis, simile and parable respectively. This indicates that retribution texts tryto convince its receivers to respect the Divine norms and avoid disobeying the Divine commandant. Simply to put, these texts seek to increase the receivers' chances ofwinning the eternal bliss and be in safe from the eternal torture and wrath.

3). As far as the overall functions of retribution texts are concerned, the stylistic and statistical analyses have shown that conative and referential functions are the only functions these texts perform. The results of the statistical analysis support this view where both conative and referential function occupy equally the highestpercentage (50\%). The other functions appear to have no role to perform in these texts.

4). The overall function of the text appears to play an essential and a leading role concerning its effects on the utilized stylistic devices and their functions in Biblical texts of retribution. In other words, the functions of the stylistic devices strongly maintains and supports the overall function(s) of their texts and vice-versa.

\section{References}

Ager, J. (2009). Heaven and Its Wonders and Hell: From Things Heard and Seen. Pennsylvania: Swedenborg Foundation.

Al-Ameedi, R., \& Al-A'ssam, S. (2018). Retribution in Qur'anic Texts: A Stylistic Analysis. British Journal of English Linguistics, 6(2), 1-18.

Arav, R. (1992). Hades, Hell. In D. Freedman, G. Herion, \& F. Pleins (Eds.), The Anchor Yale Bible Dictionary (Vol. 5, pp. 3320-3323). New York: Doubleday Dell Publishing Group, Inc.

Artherstone, A. (2009). Divine Retribution: A Forgotten Doctrine. Themelios: An International Journal for Students of Theological and Religious Studies, 34(1), 50-62.

Berlejung, A. (2015). Sin and Punishment: The Ethics of Divine Justice and Retribution in Ancient Near Eastern and Old Testament Texts. A Journal of Bible and Theology, 69(3), 272-287. https://doi.org/10.1177/0020964315578205

Bernstein, A. (1993). The Formation of Hell: Death and Retribution in the Ancient and Early Christian Worlds. London: UCL Press Limited.

Boston, T. (1850). The Whole Works of the Late Reverend Thomas Boston of Ettrick. Aberdeen: George and Robert King.

Collins, A. (1996). Hades. In P. Achtemeier (Ed.), The HarperCollins Bible Dictionary (pp. 395-396). New York: Harper Collins Publishers, Inc.

Cue, P. (2017). 11. The Sheep and The Goats (Matthew 25:31-46). Retrieved from https://bible.org/seriespage/11-sheep-and-goats-matthew-2531-46

Crystal, D., \& Davy, D. (1969). Investigating English Style. London: Longman. 
Easton, M. (1997). Eastons Bible Dictionary: A Dictionary of Bible Terms. In The Ages Digital Library Reference. Albany, OR: Ages Software, Version 2.0. Retrieved from www.ntslibrary.com/PDF\%20Books/Eastons\%20Bible\%20Dictionary.pdf

Eubank, N. (2013). What does Matthew Say about Divine Recompense? On the Misuse of the Parable of the Workers in the Vineyard (20.1-16). A Journal for the Study of the New Testament, 35(3), 242-262. https://doi.org/10.1177/0142064X12472117

Fowel, S. (2011). Being Blessed: Wealth, Property, and Theft. In S. Hauerwas \& S. Wells (Eds.), The Blackwell Companion to Christian Ethics (2nd ed., pp. 493-505). West Sussex: Wiley Blackwell Publishing Ltd. https://doi.org/10.1002/9781444396683.ch37

Horvath, T. (1993). Eternity and Eternal Life: Speculative Theology and Science in Discourse. Canada: Wilfrid Laurier University Press.

Jakobson, R. (1960). Closing Statement: Linguistics and Poetics. In T Sebeok (Ed.), Style in Language (pp. 350-377). Cambridge: Massachusetts Institute of Technology Press.

Jervis, L. (2015). Divine Retribution in Romans. A Journal of Bible and Theology, 69(3), 323-337. https://doi.org/10.1177/0020964315578209

Kaminsky, J. (2015). Would You Impugn My Justice? A Nuanced Approach to the Hebrew Bible's Theology of Divine Recompense. A Journal of Bible and Theology, 69(3), 299-310. https://doi.org/10.1177/0020964315578207

Kangwa, J. (2016). The role of the theology of retribution in the growth of Pentecostal-Charismatic churches in Africa. A Journal of Verbum et Ecclesia, 37(1), 1-9. http://dx.doi.org/10.4102/ve.v37i1.1542.

Kardec, A. (2003). Heaven and Hell: The Divine Justice Vindicated in the Plurality of Existence. New York: Spiritist Alliance for Books.

Lambrou, M. (2016). Discourse Stylistics. In Sotirova (Eds.), The Bloomsbury Companion to Stylistics. London: Bloomsbury Academic Publishing Plc.

Leech \& Short, M. (2007). Style in Fiction: A Linguistic Introduction to English Fictional Prose (2nd ed.). Edinburgh Gate: Pearson Education Limited.

Lewis, T. (1992). Dead, A Bode of The. In D. Freedman, G. Herion, \& F. Pleins (Eds.), The Anchor Yale Bible Dictionary, 5, 1926-1932. New York: Doubleday Dell Publishing Group, Inc.

M'Caig, A. (1915). Retribution. In J. Nuelsen \& G. Mullins (Eds.), International Standard Bible Encyclopedia, IV, 2570-2572. Chicago: The Howard-Severance Company.

Milikowsky, C. (1988). Which Gehenna? Retribution and Eschatology in the Synoptic Gospels and in Early Jewish Texts. A Journal of New Test. Stud., 34(1), 238-249. https://doi.org/10.1017/S0028688500020038.

Moule, C. (1982). Essays in New Testament Interpretation. Cambridge: Cambridge University Press. https://doi.org/10.1017/CBO9780511897160

Perkins, P. (1996). Hell. In P. Achtemeier (Ed.), The HarperCollins Bible Dictionary (pp. 413-415). New York: Harper Collins Publishers, Inc.

Russell, J. (2006). Heaven and Hell. In R. Segal (Ed.), The Blackwell Companion to the Study of Religion (pp. 271-284.). Oxford: Blackwell Publishing Ltd.

Thorndike, E., \& Barnhart, C. (1968). High School Dictionary (5th ed.). Glenview: Scott, Foresman and Company.

Towner, W. (1996). Retribution. In P. Achtemeier (Ed.), The Harper Collins Bible Dictionary (pp. 927-929). New York: Harper Collins Publishers, Inc.

Wong, K. (2001). The Idea of Retribution in the Book of Ezekiel. Netherlands: Koninklijke Brill N V, Leiden. https://doi.org/10.1163/9789047401056

www. 1 (2017). Retribution. Retrieved from http://etymoline.com/index.php?term=retribution

www. 2 (2017). Retribution in the World to Come. Retrieved from http://www.biblegateway.com/resources/encyclopedia-of-the-bible/Retribution

www. 3 (2017). The Future Revelation of Kingdom People. Retrieved from https://www.biblegateway.com/resources/commentaries/IVP-NT/Matt/Future-Revelation-Kingdom 
www. 4 (2017). The 4 Enemy's $\quad$ Weeds. $\quad$ Retrieved from https://www.biblegateway.com/resources/commentaries/IVP-NT/Matt/Enemys-Weeds

www. 5 (2017). The Separation. $\quad$ Retrieved from https://www.easyenglish.bible/biblecommentary/matthew-lbw.htm

www. 6 (2017). Commentaries for the Book of Matthew. Retrieved from https://www.biblestudytools.com/commentaries/scofield-reference-notes/matthew/matthew-8.html\#mt8_20

www. 7 (2017). Matthew 25:31-46 Biblical Commentary. Retrieved from https:/www.sermonwriter.com/biblicalcommentary/matthew-2531-46

\section{Copyrights}

Copyright for this article is retained by the author(s), with first publication rights granted to the journal.

This is an open-access article distributed under the terms and conditions of the Creative Commons Attribution license (http://creativecommons.org/licenses/by/4.0/). 